\title{
A Systematic Review on Sleep Related Disorders and Periodontal Disease
}

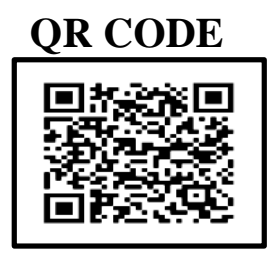

\section{RAHUL KUMAR ${ }^{1}$, RUPALI KALSI ${ }^{2}$, STUTI GUPTA*3, (D) NEETIKA GUPTA ${ }^{4}$}

BACKGROUND: Periodontitis has been implicated in many systemic diseases such as diabetes, cardiovascular diseases, hypertension, stroke, Obesity, Kidney disorders. Recent scientific evidence has revealed a relationship between sleep related breathing disorders (SRBDs) and periodontal diseases. There has been a recent scientific evidence on population based studies reflecting an association between periodontal diseases and OSA.

AIM: The tenet of the study was to find out interconnect between obstructive sleep apnea and periodontal disease.

METHODS: A systematic review of clinical trials assessing the relationship between OSA and periodontitis was carried out. An electronic search based on internet search sites (From 2000-2016) by PubMed, MEDLINE, SCOPUS, EMBASE, Google scholar, CINAHL, and Web of Science (WoS) were used. Studies which met the inclusion criteria were further analysed to find out the outcome of the study.

RESULTS: A total of 174 potentially qualifying studies were screened. Out of them 10 studies fulfilled the inclusion criteria which were further analysed. In our study 10 studies (2000-2016) from Jordan, Tokyo, Turkey, Saudi Arabia, India, USA, South Korea, Taiwan, Australia were shortlisted. Out of them 5 were cross sectional studies, 4 were case control, and 1 was meta-analysis. The sample size in the studies ranged from 66 to 30,120 adult falling in age range of 18 to 75 . The indicators for OSA used were as positive Epsworth sleepiness scale (ESS), Berlin Questionnaire, STOP-bang questionnaire, Apnea-Hypopnea index, Polysomnography (PSG). And the indicators for periodontal disease were Plaque index (PI), Clinical attachment level (CAL), Pocket Probing Depth (PPD), Gingival Bleeding Index (GBI). Majority of studies showed positive correlation between OSA and periodontal disease.

CONCLUSION: Recent evidence and literature suggests that there exist a strong interconnect between OSA and periodontal disease. Dentist play a pivotal role in diagnosis and timely management of OSA cases so as to halt progression of sleep apnea and periodontitis.

KEYWORDS: Sleep Related Breathing Disorders (SRBDS), Obstructive Sleep Apnea(OSA), Epsworth Sleepiness Scale(ESS), Apnea-Hypopnea Index (AHI), Polysomnography (PSG)

\section{INTRODUCTION}

Periodontal disease is a multifactorial disease that affects only a limited number of people within a population. Periodontal disease is a chronic infection of the tooth supporting structures caused mainly by gram-negative anaerobes. ${ }^{1}$ Periodontal infection can be modified by behavioural factors, hormonal imbalances, drugs, systemic conditions, immunological, factors and haematological disorders. ${ }^{2}$ Recently periodontal disease has received increasing attention because it may have relationship to systemic disease like Obstructive Sleep Apnea (OSA), diabetes, coronary heart disease, osteoporosis, etc.3,4

OSA is an event in which there is sudden obstruction or decrease in airflow due to collapse of upper airway leading to transient hypoxia and disturbed sleep.

Symptoms of OSA include morning headache, daytime sleepiness, snoring, and breathing pauses during sleep. 5 Excessive Daytime Somnolence (EDS) is a key symptom of
OSA characterized by persistent sleepiness and often a general lack of energy, even during the day after apparently adequate or even prolonged night-time sleep. It is estimated that nearly $80 \%$ of men and $93 \%$ of women with moderate to severe sleep apnea are undiagnosed. ${ }^{6}$ There has been a recent scientific evidence of association between periodontal diseases and OSA.

Thus, periodontitis is a multifactorial disease has polymicrobial etiology modified by various systematic and environmental factors. The periodontal and systemic diseases has a two way connect.

Numerous researches have been published focusing relationship between diabetes, pregnancy, Cardiovascular diseases and periodontitis. Very few studies are carried out to indicate relationship between OSA and periodontitis. Thus, it is important to find out the link between OSA and periodontal disease in an attempt to establish it as a risk 
factor.

\section{METHODOLOGY}

This systematic review was conducted based on PRISMA. The research questions were explored using the PICO method. The research question were: (1) Is there a relation between periodontal disease and obstructive sleep apnea? (2) What is the interconnect between chronic periodontitis and obstructive sleep apnea? (3) What are the factors which suggest the relationship between periodontal disease and obstructive sleep apnea?

Search strategy: An electronic search of SCOPUS, MEDLINE, PubMed, CINAHL, Google Scholar and Web of Science (WoS) was carried out considering articles published up to December 2016 in English language.

Inclusion criteria: To be included studies had to be epidemiological studies regarding the outcome of reflecting the relationship between OSA and periodontal disease patients. The studies had to display the diagnosis of periodontitis based on key parameters like PPD, CAL, PI, GBI. The evaluation of OSA based on screening questionnaire like ESS, Berlin questionnaire, STOP-bang questionnaire, Mallampatti score and polysomnography (PSG) was a prerequisite. Various longitudinal studies, cohort studies, case control studies, randomized controlled trails on humans with no restrictions on sample size and geographic location published between (2000-2016) were enrolled in this study.

Exclusion criteria: Case Reports, Systematic reviews, review articles, abstracts, animal studies, publications in languages other than English were excluded from this study. Studies which did not directly evaluate the relationship between OSA and periodontitis were also excluded from the study. (Figure 1 )

\section{ASSOCIATION BETWEEN OSA AND PERIODONTAL DISEASE}

The relationship between periodontitis and obstructive sleep apnea (OSA) had not been investigated before the study by Gunaratnam et al. (2009). ${ }^{7}$ Periodontitis and OSA both are associated with systemic inflammation and cardiovascular disease. There is plethora of evidence implicating chronic periodontitis as a synergistic cause of various diseases, adverse pregnancy outcomes, pulmonary and cardiovascular diseases due to potential inflammatory pathways. There has been a recent scientific evidence of association between periodontal diseases and OSA. (Figure 2) Kellar JJ et al. ${ }^{8}$ (2013) carried out a population based study showing statistically significant difference in the prevalence of chronic periodontitis in patients suffering from OSA. Arora SA et al. ${ }^{9}$ (2015) in their cross-sectional study analysed interconnection between periodontal disease \& day time somnolence among 200 patients using Epsworth sleeping scale. Results revealed a strong relationship between severity of periodontal diseases and

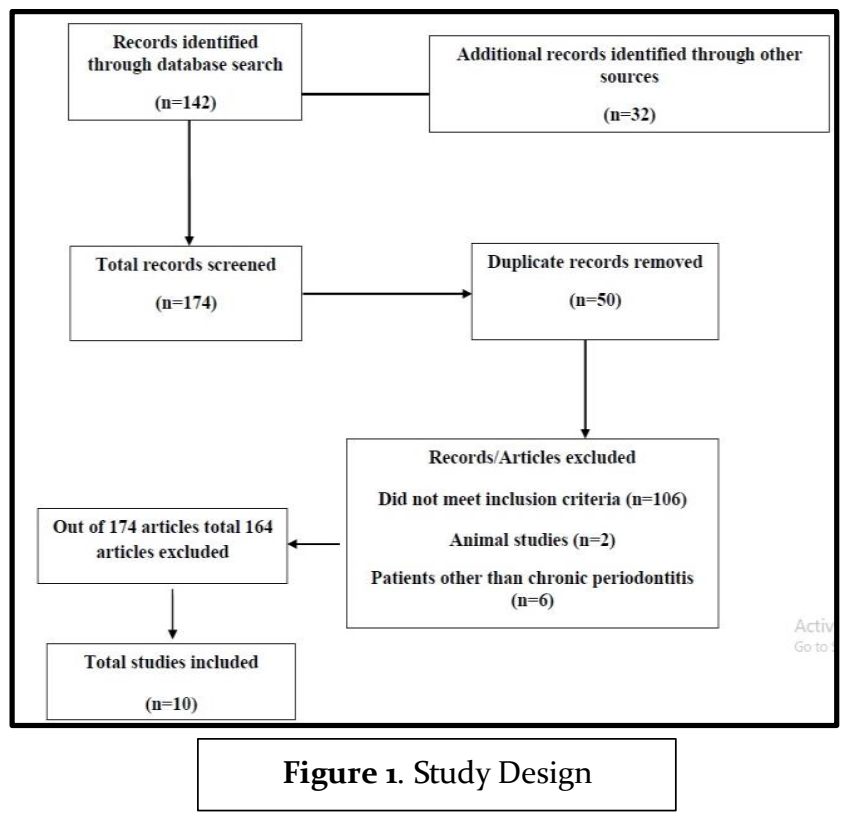

daytime somnolence, although not statistically significant. Symptoms of OSA include morning headache, daytime sleepiness, snoring, and breathing pauses during sleep. ${ }^{10}$ Excessive Daytime somnolence (EDS) is a key symptom of OSA characterized by persistent sleepiness and often a general lack of energy, even during the day after apparently adequate or even prolonged nighttime sleep. ${ }^{11}$ The presence of obstructive sleep apnea is determined by the ApneaHypopnea Index (AHI). An AHI $\geq 5$ is indicative of the presence of obstructive sleep apnea. ${ }^{12}$

Various screening questionnaires are used to assess the screening of OSA, (i) Epsworth Sleepiness Scale(ESS) ${ }^{13}$ :Which is used as a tool to assess excessive day time sleepiness/Somnolence. The Epworth Sleepiness Scale is widely used in the field of sleep medicine as a subjective measure of a patient's sleepiness. The test is a list of eight situations in which the patient rates his/her tendency to become sleepy on a scale of o(no chance of dozing) to 3 (high chance of dozing). Upon completion of the test, the values for the responses are added and the total score is based on a scale of o to 24. The scale estimates whether a person is experiencing excessive sleepiness that possibly requires medical attention. Epsworth sleepiness scale is used as a validated, reproducible, and sensitive tool for the assessment and quantification of daytime sleepiness. (ii) Berlin questionnaire ${ }^{14}$ (Netzer $\mathrm{NC}$ et al.) Berlin questionnaire includes a set of questions concerning various known risk factors and symptoms of OSA. The Berlin questionnaire is simple and very easy for the screening of large populations. It does not require any extensive medical training to help patients to fill up as well as to analyze the questionnaire. Its sensitivity, specificity, and predictive values are sufficient for early diagnosis of OSA. (iii) Stop-bang questionnaire15: (STOP) S-Snore, TTired, O-Observed, P-Blood pressure. (BANG) B-Body mass 


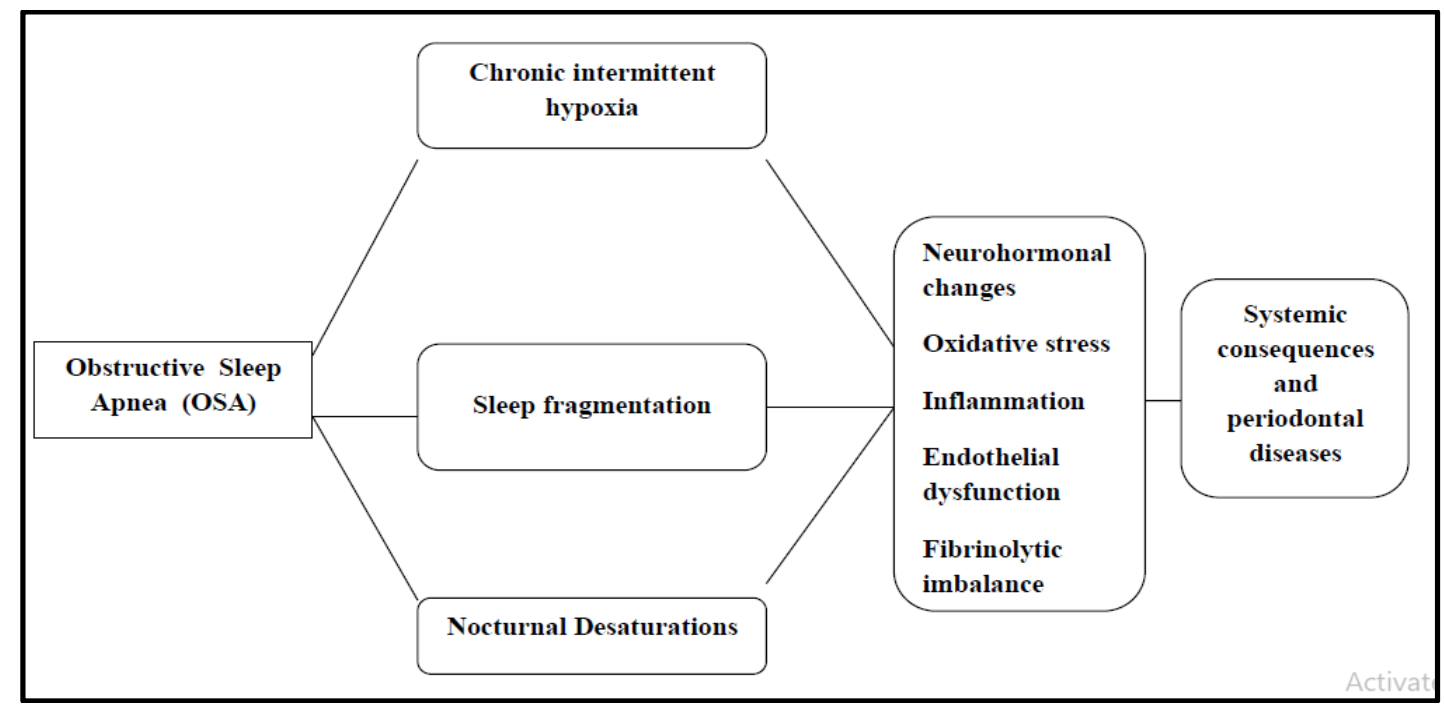

Figure 2. Mechanism leading to systemic consequences \& periodontal disease of Obstructive Sleep Apnea (OSA).

index, A-Age, N-neck, G-Gender Yes to > 3 questions-High risk of obstructive sleep apnea. Yes to $>3$ questions- Low risk of obstructive sleep apnea. These are used for screening of OSA. A confirmed diagnosis is made by Polysomnography (PSG) which is the gold standard. PSG includes electroencephalogram (ECG), electrooculogram (EOG), electromyogram (EMG). ${ }^{16}$

\section{RESULTS}

Selection of studies: A systematic review methodology was followed, and a thorough database search was done which yielded 142 records. Additional sources yielded 32 more records. A total number of 174 records from year 2000-2016 were taken into consideration; 50 duplicate records were removed from total of 174. 106 records which did not meet inclusion criteria, animal studies $(n=2)$, patients other than chronic periodontitis $(n=6)$ were also excluded to the study. Out of these records, a total number of 10 shortlisted studies were further evaluated on the basis of inclusion criteria and were included in the study. Statistical synthesis of the results of the included studies was not possible. Thus the paper was analysed on a qualitative way as meta-analysis was not possible. Out of 10 studies which were short listed for the systematic review 6 were cross sectional studies, 3 case control and 1 metaanalysis. 9 studies have reported a positive co-relation between OSA and periodontal disease whereas one study by Loke et al. ${ }^{19}$ (2014 USA) reported that relation between OSA and Periodontitis is not significant.

Various cross-sectional studies are done till now to evaluate relationship between OSA and periodontitis (Table. 1) Habashneh RA et al. ${ }^{17}$ (2016, Jordan) identified the cases of
OSA using the Berlin questionnaire and reported a positive association between periodontitis and OSA in a crosssectional study on 296 patients. Their study showed a positive association between periodontitis and HR-OSA which was more generalized and more severe than in LROSA patients. Suzuki S et al. ${ }^{18}$ (2016, Tokyo) did a cross sectional study by using Epsworth sleepiness scale (ESS) questionnaire and results revealed association between risk of OSA and poor oral health status. Theirs was an internet based survey involving 3053 respondents; the OSA group included 493 patients and control group consisted of 2560 patients. Epsworth sleepiness scale questionnaire was given to all the participants along with a consent form. Significant correlations were observed with the following parameters: difficulty in opening mouth, dry mouth, bad breath, gingival bleeding and gingival swelling. Gamsiz-Isik H et al. ${ }^{19}$ (2016, Turkey) used polysomnography (PSG) for the diagnosis of OSA in periodontitis patients. Results of their cross sectional study demonstrated a higher prevalence of periodontitis and higher levels of levels of GCF IL-1 $\beta$ and serum hs-CRP in OSA patients with the prevalence of periodontitis in the OSA group (96.4\%) being significantly higher than in the control group $(75 \%)$, $(\mathrm{p}<\mathrm{o.001})$. Severe periodontitis prevalence was higher in the OSA group than in the control group. All periodontal clinical parameters were significantly higher in patients with OSA than in the controls $(\mathrm{p}=0.001)$.

Arora SA et al.9 (2015, India) used the Epsworth Sleepiness Scale (ESS) as a diagnostic questionnaire and their results suggested a strong relationship between severity of periodontal disease and OSA and documented that as the mean CAL \& PPD scores increased the ESS scores also 
increased. It was found to be $7.6+1.97$ for localized Periodontitis patients and $7.25+1.30$ for Generalized Chronic Periodontitis subjects. Loke et al. ${ }^{20}$ (2014 USA) used polysomnography (PSG) for diagnosis of OSA. They reported that OSA was not significantly associated with the presence of moderate or severe periodontitis. In their study, 100 patients diagnosed with an overnight polysomnogram from sleep study centre underwent periodontal examination measuring periodontal probing depth (PD), clinical CAL, gingival recession, percentage of site with bleeding on probing. Multivariable logistic regression analysis predicting association between moderate/severe periodontitis with AHI score, age, smoking status indicated a significant association with age but no significant association with OSA.

A study conducted by Seo et al. ${ }^{21}$ (2013, Korea) consisted of 687 subjects. They evaluated the association between OSA onset and progression of periodontal disease measuring periodontal parameters (CAL, periodontal probing depth). OSA was determined using polysomnography and apneahypopnea index (AHI). Their Results indicated that $17.5 \%$ of patients had periodontitis, $46.6 \%$ had OSA and $60 \%$ who were diagnosed with periodontitis had OSA proving a significant association between OSA and periodontal disease (Table 2).

Jewair AL et al.22 (2015, Saudi Arabia) did a meta-analysis of 4 studies considered as randomized controlled trials, Preferred Reporting Items for Systematic reviews and meta Analyses followed by (PRISMA) guidelines. Results of the study showed a plausible association between periodontal disease and OSA. Evidence on the efficacy of periodontal disease interventions is insufficient. Various clinical and radiographical parameters were used for the periodontal assessment were CAL, PPD, oral hygiene indices, radiographic alveolar bone loss, and salivary cytokines. The (pooled odds ratio $=1.65,95 \%$ confidence interval $(\mathrm{CI})=\mathbf{1 . 1 1}$, 2.46, $\mathrm{P}=0.01$ ) respectively.

Case control studies also determined the relationship between OSA and periodontitis. (Table.3) Moreover, Keller et al.9 (2013, Taiwan) through their case-control study design determined that there is an association between OSA and chronic periodontitis using Polysomnography as the diagnostic test. Ahmad et al. ${ }^{18}$ (2013, USA) through a case control study used a "STOP" OSA screening questionnaire to assess the

OSA and it was found that a significant association between moderate or severe periodontitis and the risk of OSA in patients. Gunaratnam et al.7 (2009, Australia) used the Apnea-hypopnea (AHI Index) in their case-control study design and their results revealed that there is significant association between periodontal disease and OSA.

\section{DISCUSSION}

Periodontal disease is a irreversible inflammatory disease of tooth supporting structure to halt the disease progression and treatment, patients need a specialist. This disease has multiple etiological factors as well as risk factors which include aging, gender, obesity, genetics, stress, pregnancy, nutrition, diabetes, smoking. Chronic periodontitis has been suggested to have an impact on the development of cardiovascular diseases, diabetes, obesity, kidney disorders and obstructive sleep apnea. ${ }^{23,24}$ Few studies have claimed that periodontitis and OSA are associated with systemic inflammation and found that prevalence of periodontitis in OSA was higher. So, for a dentist the knowledge of OSA is mandatory to diagnose and manage cases of periodontitis.

Numerous studies have done till date which have hypothesized the relationship between OSA and periodontitis. With this review, we have attempted to find out the pathophysiology of OSA and periodontal disease.

In OSA, patients mouth breathing is a classical feature which leads dryness of mouth. It can be attributed to dryness of mouth in OSA patients. Snoring leads to mouth breathing which is seen in OSA patients, There are few studies which have suggested that dry mouth affects periodontal structures because saliva does not provide clearance action into the periodontal pocket which leads to bacterial colonization and binding of bacteria to the tissues which development of periodontal diseases like gingivitis and periodontitis occurs. ${ }^{24}$ Apart from dryness of mouth while sleeping it also leads to halitosis. Stress is found to be higher in OSA patients, as we know stress plays a major role in periodontal disease occurrence and stress related periodontal disease. Some authors also evaluated that Plaque index (PI) was higher in OSA patients and daily brushing habits was also seen lower in OSA patients. A study reported in Japanese children with OSA and poor oral hygiene was also seen. ${ }^{24}$

Certain studies suggest the role of OSA with various inflammatory mediators TNF- $\propto$, IL-1 $\beta$, IL-6, process through hypoxia and oxidative stress, hypoxia in OSA patients leads to stimulation which release of reactive oxygen species (ROS) that can lead to inflammation and endothelial dysfunction. OSA patients shown high levels of pro-inflammatory mediators and high levels of C-reactive protein such as seen in periodontitis patients. ${ }^{25}$ There for, the exact mechanism to see impact on OSA and periodontitis on systemic health are unclear, their effect on pro-inflammatory cytokine have suggested.26,27 During inflammatory response elevated levels of TNF- $\propto$, I L-1b and $C$-reactive level in gingival crevicular fluid have been seen in periodontal disease patients. In OSA patients there is repeated events of hypoxia and apnea which leads to an increase levels of TNF- $\propto$, interleukin- 6 and C-reactive 


\begin{tabular}{|c|c|c|c|c|c|c|}
\hline STUDY & $\begin{array}{l}\text { STUDY } \\
\text { DESIGN }\end{array}$ & DEMOGRAPHY & $\begin{array}{l}\text { PERIODONTAL } \\
\text { ASSESEMENT }\end{array}$ & $\begin{array}{l}\text { DIAGNOSIS OR } \\
\text { RISK FOR OSA }\end{array}$ & RESULTS & INFERENCE \\
\hline $\begin{array}{l}\text { Habashneh RA } \\
\text { et al.22 } 2016 \\
\text { Jordan }\end{array}$ & $\begin{array}{l}\text { Cross- sectional } \\
\text { internet survey }\end{array}$ & $\begin{array}{c}\mathrm{n}=296 \text { subjects. } \\
\text { Males with a mean } \\
( \pm \text { SD) age } 40(8.5) \\
\text { years selected }\end{array}$ & $\begin{array}{c}\mathrm{CAL}>3 \mathrm{~mm}, \mathrm{PPD}> \\
4 \mathrm{~mm}, \mathrm{GI}^{*}, \mathrm{PI}, \mathrm{CI}^{*} \\
\text { presence or absence, } \\
\text { BOP\# }\end{array}$ & $\begin{array}{c}\text { Berlin- } \\
\text { questionnaire }\end{array}$ & $\begin{array}{l}15 \% \text { patients considered as (HR-OSA) } \\
\text { with (LR-OSA) PPD- } 2.35 \pm 0 . \pm 69 \text { vs } \\
1.97 \pm 0.34(\mathrm{p}=0.000) \text { and } \\
\text { CAL } 2.95 \pm 0.82 \text { vs } 2.12 \pm 0.55(\mathrm{p}=0.000) \text {, } \\
\text { patients with HR-OSA were more } \\
\text { likely to have periodontitis }(\mathrm{OR}=2.3 \text {; } \\
95 \% \text { CI: } 1.03-5.10) \text { compared to } \\
\text { patients with LR-OSA) }\end{array}$ & $\begin{array}{l}\text {-The study showed a positive } \\
\text { association between periodontitis } \\
\text { and HR-OSA. Periodontitis in HR- } \\
\text { OSA patients was more } \\
\text { generalized and more severe than } \\
\text { in LR-OSA patients. }\end{array}$ \\
\hline $\begin{array}{l}\text { Suzuki S et al. }{ }^{23} \\
\text { 2016, Tokyo }\end{array}$ & $\begin{array}{l}\text { Cross- sectional } \\
\text { internet survey }\end{array}$ & $\begin{array}{l}\text { Total } 3053 \\
\text { respondents. } \\
\text { OSA group- } 493 \\
\text { patients and } \\
\text { Control group- } \\
\text { 2,56o patients. }\end{array}$ & $\begin{array}{l}\text { Gingival index (GI) } \\
\text { Gingival swelling (GI), } \\
\text { dry mouth, bad breath, } \\
\text { tooth mobility, } \\
\text { Brinkman index } \\
\text { (smokers) }\end{array}$ & $\begin{array}{c}\text { Epsworth } \\
\text { sleepiness scale }\end{array}$ & $\begin{array}{l}\text { Significant correlation were observed } \\
\text { with the following parameters: } \\
\text { difficulty in opening mouth (odds } \\
\text { ratio:2.66 } 95 \% \text { confidence interval } \\
\text { (CI): 1.647-4.311), dry mouth ( OR:2.11; } \\
\text { CI: 1.544-2.876), bad breath (OR: } \\
\text { 1.69: CI: 1.309-2.186), gingival } \\
\text { bleeding (OR: 1.48; CI: 1.134-1.932) } \\
\text { and gingival swelling (OR: 1.44; CI: } \\
\text { 1.046-1.981) }\end{array}$ & $\begin{array}{l}\text {-This study revealed association } \\
\text { between risk OSA and oral health } \\
\text { status. } \\
\text {-Some limitations-Survey was a } \\
\text { self reported questionnaire. } \\
\text {-Internet survey can be a source of } \\
\text { selection bias. No questions were } \\
\text { asked regarding other possible } \\
\text { causes of mouth breathing, such } \\
\text { as allergic rhinitis. }\end{array}$ \\
\hline $\begin{array}{l}\text { Gamsiz-Isik H } \\
\text { et al. }{ }^{24} \text { Turkey }\end{array}$ & Cross sectional & $\begin{array}{l}163 \text { individuals: } 83 \\
\text { individuals with } \\
\text { OSA (18 females; } \\
65 \text { males) and } \\
80 \text { non-OSA } \\
\text { individuals ( } 23 \\
\text { females; } 57 \text { males) } \\
\text { as controls. The } \\
\text { test group was } \\
\text { classified } \\
\text { according to OSA } \\
\text { severity. }\end{array}$ & $\begin{array}{c}\mathrm{CAL}^{*}, \mathrm{PPD} \mathrm{G} \mathrm{GI}^{*}, \mathrm{PI}^{*}, \\
\text { BOP\#, } \\
\mathrm{GCF}^{*} \text { IL-1 } \beta\end{array}$ & $\begin{array}{c}\text { Polysomnograph } \\
y \\
\text { OSA diagnosed if } \\
\text { AHI was } \\
>5 \text { events } / \text { hr. }\end{array}$ & 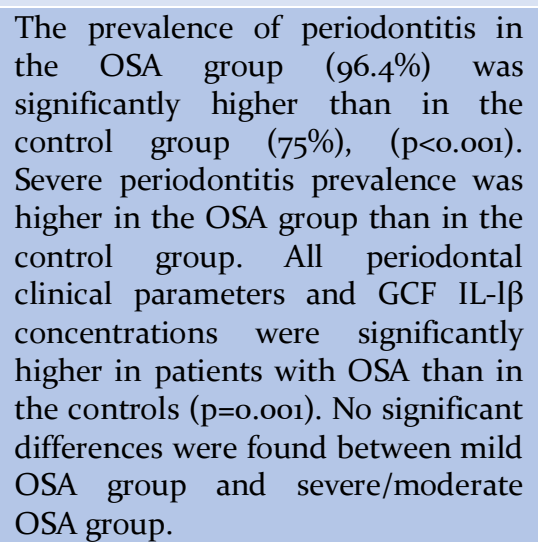 & $\begin{array}{l}\text {-This study demonstrated a higher } \\
\text { prevalence of periodontitis and } \\
\text { higher levels of GCF IL-1 } \beta \text { and } \\
\text { serum hs-CRP in OSA patients. }\end{array}$ \\
\hline
\end{tabular}




\begin{tabular}{|c|c|c|c|c|c|c|}
\hline STUDY & $\begin{array}{l}\text { STUDY } \\
\text { DESIGN }\end{array}$ & DEMOGRAPHY & $\begin{array}{l}\text { PERIODONTAL } \\
\text { ASSESEMENT }\end{array}$ & $\begin{array}{l}\text { DIAGNOSIS OR } \\
\text { RISK FOR OSA }\end{array}$ & RESULTS & INFERENCE \\
\hline $\begin{array}{l}\text { Arora SA et al.2o } \\
\text { 2015, India }\end{array}$ & Cross-sectional & $\begin{array}{l}\text { Sample size- } 200 \\
\text { subjects } 119 \\
(59.5 \%) \text { males, } 79 \\
(39.4 \%) \text { females }\end{array}$ & $\begin{array}{l}\mathrm{CAL}^{*}, \mathrm{PD} \#, \mathrm{GI}^{*}, \mathrm{PI}^{*}, \\
\text { gingivitis, periodontitis } \\
\text { according to AAP } \\
\text { classification. }\end{array}$ & $\begin{array}{c}\text { Epsworth } \\
\text { sleepiness scale }\end{array}$ & $\begin{array}{l}\text {-Prevalence of mild gingivitis } \\
\text { to severe periodontitis: } 15 \% \text { had } \\
\text { gingivitis, localized periodontitis } \\
43 \% \text {, generalized periodontitis } 32 \% \text {, } \\
\text { diagnosed as chronic periodontitis. } \\
\text {-Mean PI score with gingivitis } \\
1.6 \pm 0.45 \text {, with mean gingival index } \\
\text { scores } 1.5 \pm 0.04 \text {, ESS score } 5.3 \pm 1.6 \\
\text { with gingivitis } \\
\text { Mean CAL\& PPD scores for localized } \\
\text { periodontitis } 7.6 \pm 1.97, \text { and for } \\
\text { chronic periodontitis } 7.25 \pm 1.30\end{array}$ & $\begin{array}{l}\text { A strong relationship between } \\
\text { severity of periodontal diseases } \\
\text { and day time somnolence, } \\
\text { although not statistically } \\
\text { significant. } \\
\text { Some limitations: There was no } \\
\text { confirmatory diagnosis of sleep } \\
\text { apnea by polysomnography and } \\
\text { other objective tools such EEG }\end{array}$ \\
\hline $\begin{array}{l}\text { Loke et al. }{ }^{19} \\
\text { 2014, USA }\end{array}$ & Cross-sectional & $\begin{array}{l}\mathrm{n}=100 \text { subjects. } \\
\text { F/M gender ratio: } \\
\text { 9/91. } \\
\text { Age range: } 28-79 \\
\text { years. } \\
\text { Mean ages: } 52.6 \\
\text { year. }\end{array}$ & $\begin{array}{c}\text {-PPD\#, CAL*, REC*, } \\
\text { BOP\#, } \% \text { of sites with } \\
\text { plaque, } \% \text { of } \\
\text { sites with bleeding on } \\
\text { probing, plaque PD } \geq 5 \\
\text { mm, } \\
\% \text { of sites with } \\
\text { CAL } \geq 3 \text { mm. }\end{array}$ & $\begin{array}{l}\text { Polysomn- } \\
\text { ography }\end{array}$ & $\begin{array}{l}\text {-Prevalence of moderate to severe } \\
\text { periodontitis } 73 \% \text {. } \\
\text { - Mean AHI in mild, moderate, and } \\
\text { severe categories }=44.0 \quad \pm \\
12.9,55 \cdot 4 \pm 13.4 \text {, } \\
58.6 \pm 12.6 \text {, and } 54.2 \pm 11.8 \text { respectively }\end{array}$ & $\begin{array}{l}\text { OSA was not significantly } \\
\text { associated } \\
\text { with the presence of moderate or } \\
\text { severe periodontitis except for } \% \\
\text { of sites with plaque. } \\
\text { Some limitations: } \\
\text {-Weak study design. } \\
\text {-Sample over represented by } \\
\text { males. }\end{array}$ \\
\hline $\begin{array}{c}\text { Seo et al. }{ }^{26} 2013 \text {, } \\
\text { Korea }\end{array}$ & Cross-sectional & $\begin{array}{l}\mathrm{n}=687 \text { subjects. } \\
\text { F/M gender ratio: } \\
227 / 460 . \\
\text { Age range: } 47-77 \\
\text { years. } \\
\text { Mean age: } \\
55.85 \pm 6.63 \text { years. }\end{array}$ & $\begin{array}{c}\text { CAL }>6 \mathrm{~mm}, \mathrm{PPD}> \\
4 \mathrm{~mm}, \mathrm{BOP}, \\
{\text { REC\#,PI*}, \mathrm{GI}^{*}}^{*}\end{array}$ & $\begin{array}{l}\text { Polysomnograph } \\
\text { y and Apnea } \\
\text { hypopnea } \\
\text { index(AHI) }\end{array}$ & $\begin{array}{l}\text {-Prevalence of periodontitis: } 17.5 \% \\
(\mathrm{~N}=120) \text {. } \\
\text {-Prevalence of OSA: } 46.6 \% \text {. } \\
\text { - } 60 \% \text { of subjects with periodontitis } \\
\text { had OSA. } \\
\text { OSA was positively associated with } \\
\text { periodontitis (OR= 2.51, } 95 \% \mathrm{CI}= \\
\text { 1.37-4.62) in subjects }>55 \text { years of age, } \\
\text { not in subjects }<55 \text { years of age. }\end{array}$ & $\begin{array}{c}\text { There is a significant association } \\
\text { between } \\
\text { OSA and periodontal } \\
\text { disease. } \\
\text { Some limitations- } \\
\text {-No sample size calculation. } \\
\text {-Not all known confounders } \\
\text { were controlled for. }\end{array}$ \\
\hline
\end{tabular}

Table 1. Cross-Sectional Studies Evaluating the Relationship Between OSA and Periodontitis and Included in the Present Study.

CAL- Clinical attachment level, PPD-Pocket probing depth, REC-Recession, GI- Gingival index, PI-Plaque index, CI-Calculus index, AHI-Apnea Hypopnea Index, BOP-Bleeding on Probing, HR-High risk, LR-Low risk ,OSA-Obstructive Sleep Apnea 


\begin{tabular}{|c|c|c|c|c|c|c|}
\hline STUDY & $\begin{array}{l}\text { STUDY } \\
\text { DESIGN }\end{array}$ & $\begin{array}{c}\text { DEMOGRAPH } \\
\mathbf{Y}\end{array}$ & $\begin{array}{l}\text { PERIODONTAL } \\
\text { ASSESEMENT }\end{array}$ & $\begin{array}{l}\text { DIAGNOSIS } \\
\text { OR RISK FOR } \\
\text { OSA }\end{array}$ & RESULTS & INFERENCE \\
\hline $\begin{array}{l}\text { Jewair AL et } \\
\text { al,.25 } 2015 \\
\text { SAUDI } \\
\text { ARABIA }\end{array}$ & $\begin{array}{l}\text { This meta- } \\
\text { analysis Study } \\
\text { considered as } \\
\text { randomized } \\
\text { controlled } \\
\text { trials, } \\
\text { longitudinal, } \\
\text { cohort, case- } \\
\text { control, } \\
\text { and } \\
\text { epidemiological } \\
\text { studies on } \\
\text { humans with } \\
\text { no } \\
\text { restrictions. }\end{array}$ & $\begin{array}{l}\text { Meta-analysis of } \\
\text { four studies }\end{array}$ & $\begin{array}{l}\text { CAL*, PPD\#, oral } \\
\text { hygiene indices, } \\
\text { radiographic alveolar } \\
\text { bone } \\
\text { loss, and salivary } \\
\text { cytokines. }\end{array}$ & $\begin{array}{l}\text { Preferred } \\
\text { Reporting } \\
\text { Items for } \\
\text { Systematic } \\
\text { Reviews and } \\
\text { Meta Analyses } \\
\text { (PRISMA) } \\
\text { guidelines }\end{array}$ & $\begin{array}{l}\text { Meta-analysis of four studies } \\
\text { revealed a statistically } \\
\text { significant association between } \\
\text { periodontal disease and OSA } \\
\text { (pooled odds ratio }=1.65,95 \% \\
\text { confidence interval }(\mathrm{CI})=1.11 \text {, } \\
2.46, \quad \mathrm{P}=0.01) \text { There is } \\
\text { insufficient evidence on the } \\
\text { efficacy of periodontal disease } \\
\text { interventions }\end{array}$ & $\begin{array}{l}\text { There is some evidence to a } \\
\text { plausible association } \\
\text { between periodontal disease } \\
\text { and OSA. Evidence on the } \\
\text { efficacy of periodontal disease } \\
\text { interventions is insufficient. }\end{array}$ \\
\hline
\end{tabular}

Table 2. Meta-Analysis Evaluating the Relationship Between OSA and Periodontitis and Included in the Present Study.

CAL- Clinical attachment level, PPD-Pocket probing depth, REC-Recession, GI- Gingival index, PI-Plaque index, CI-Calculus index, AHI-Apnea Hypopnea Index, BOP-Bleeding on Probing, HR-High risk, LR-Low risk ,OSA-Obstructive Sleep Apnea 


\begin{tabular}{|c|c|c|c|c|c|c|}
\hline STUDY & $\begin{array}{l}\text { STUDY } \\
\text { DESIGN }\end{array}$ & DEMOGRAPHY & $\begin{array}{l}\text { PERIODONTAL } \\
\text { ASSESEMENT }\end{array}$ & $\begin{array}{l}\text { DIAGNOSIS OR } \\
\text { RISK FOR OSA }\end{array}$ & RESULTS & INFERENCE \\
\hline $\begin{array}{l}\text { Keller et al }{ }^{17} \text {. } \\
\text { 2013, Taiwan }\end{array}$ & $\begin{array}{l}\text { They conducted } \\
\text { study on } \\
\text { longitudinal } \\
\text { health insurance } \\
\text { datatbase } 2000 . \\
\text { (Case-control } \\
\text { study) }\end{array}$ & $\begin{array}{l}\text { Cases }=7673 \text { with } \\
\text { OSA as cases- } \\
\text { Controls }=21,963 \\
\text { without OSA. } \\
\text { Mean ages }=47.6 \\
( \pm 15.4 \text { years }) \text {. and } \\
\text { over } 62 \% \text { were } \\
\text { males }\end{array}$ & $\begin{array}{l}\text { - PPD } \geq 3 \mathrm{~mm} \text {, inspection } \\
\text { of color and shape of } \\
\text { gingival tissue, BOP\#, } \\
\text { tooth mobility. } \\
\text {-Radiographic alveolar } \\
\text { bone loss. }\end{array}$ & $\begin{array}{l}\text { Polysomnograph } \\
\text { y }\end{array}$ & $\begin{array}{l}\text {-Prevalence of periodontitis between } \\
\text { cases and control: ( } 33.8 \% \text { of cases vs. } \\
22.6 \% \text {, }<<0.001 \text { ) conditional logistic } \\
\text { regression analysis revealed that the } \\
\text { OR of prior CP for cases } 1.75(95 \% \\
\text { CI=1.68-1.88; P <0.0o1) OR for OSA } \\
\text { among sampled patients with prior } \\
\text { CP after excluding those who } \\
\text { underwent periodontal treatment } \\
1.78 \text { ( } 95 \% \mathrm{CI}=1.68-1.88 ; \mathrm{P}<0.001) \text {. }\end{array}$ & $\begin{array}{l}\text {-There was an association } \\
\text { between OSA and a prior } \\
\text { diagnosis of chronic } \\
\text { periodontitis. } \\
\text { Some limitations- } \\
\text {-Risk of measurement bias. } \\
\text {-No clear definition of chronic } \\
\text { periodontitis. } \\
\text {-Multiple examiners. }\end{array}$ \\
\hline $\begin{array}{l}\text { Ahmad et al }{ }^{18} \\
2013, \text { USA }\end{array}$ & Case-control & $\begin{array}{l}\text { According to AAP } \\
\text { classification } \\
\text { Cases=50 with } \\
\text { moderate or severe } \\
\text { periodontitis was } \\
\text { selected as; } \\
\text { Case types III, IV } \\
\text { With the Mean } \\
\text { ages=61 years. } \\
\text { Controls=104 with } \\
\text { gingivitis } \\
\text { Or early } \\
\text { periodontitis with } \\
\text { OSA were } \\
\text { included Case } \\
\text { types I, II }\end{array}$ & $\begin{array}{l}\text { Plaque Index, Gingival } \\
\text { Index and Bleeding } \\
\text { Index, } \mathrm{PD}^{\#}, \mathrm{CAL}^{*} \text {, } \\
\text { gingival recession and } \\
\text { case types }\end{array}$ & $\begin{array}{l}\text { “STOP” OSA } \\
\text { screening } \\
\text { questionnaire }\end{array}$ & $\begin{array}{l}\text { In all, } 59 \text { subjects }(38.3 \%) \text { screened at } \\
\text { high risk for OSA by providing } 2 \text { or } \\
\text { more affirmative response on the } \\
\text { STOP questionnaire. } 60 \% \text { of } \\
\text { periodontitis cases }(n=30) \text { screened } \\
\text { high risk of OSA compared with only } \\
28 \% \text { of controls ( } n=29) \text {. Cases were } \\
4.1 \text { times more likely ( } 95 \% \text { CI: } 1.9 \text {, } \\
11.4 \text { ) to at high risk of OSA than } \\
\text { controls ( } \mathrm{p}=0.007 \text { ) after adjustment } \\
\text { for potential confounders. }\end{array}$ & $\begin{array}{l}\text { There is a significant association } \\
\text { between } \\
\text { moderate or severe } \\
\text { periodontitis and the risk of OSA. } \\
\text { Some limitations: } \\
\text {-Risk of measurement bias } \\
\text { (periodontal examinations were } \\
\text { done by different operators, no } \\
\text { calibration results). } \\
\text { - OSA was subjectively } \\
\text { ascertained. } \\
\text { - No goodness of fit statistic. }\end{array}$ \\
\hline $\begin{array}{l}\text { Gunaratnam et } \\
\text { al }^{29} 2009, \\
\text { Australia }\end{array}$ & Case-control & $\begin{array}{l}\text { Cases- } 66 \text { ( } 54 \text { males } \\
12 \text { females) }\end{array}$ & $\begin{array}{l}\mathrm{CAD}^{\#}, \mathrm{CAL}^{*}, \mathrm{REC}^{*}, \mathrm{BoP} \# \\
\text { (Silness and Loe plaque } \\
\text { index (PI), Lobene } \\
\text { modified gingival index } \\
\text { (GI) }\end{array}$ & $\begin{array}{l}\text { AHI of more than } \\
\text { five per hour }\end{array}$ & $\begin{array}{l}\text { Prevalence of periodontitis was } 77 \% \\
\text { and } 79 \% \text { depending on definitions } \\
\text { used, Mean } A H I=36.55 \pm 25.7 \\
\text { Mean CAL }=2.15 \pm 1.20 \mathrm{~mm} \text {, CAL } \\
\text { significantly associated with total } \\
\text { sleep time }(r=0.287,0<0.5\end{array}$ & $\begin{array}{l}\text {-Study shows significant relation } \\
\text { between OSA and periodontal } \\
\text { disease. } \\
\text {-Some limitations: } \\
\text {-Small sample size. }\end{array}$ \\
\hline
\end{tabular}

Table 3. Case Control Studies Evaluating the Relationship Between OSA and Periodontitis and Included in the Present Study.

CAL- Clinical attachment level, PPD-Pocket probing depth, REC-Recession, GI- Gingival index, PI-Plaque index, CI-Calculus index, AHI-Apnea Hypopnea Index, BOP-Bleeding on Probing, HR-High risk, LR-Low risk ,OSA-Obstructive Sleep Apnea 
protein in the serum of OSA patients. ${ }^{28,29}$ One study assessed the concentrations of a number of salivary cytokines (IL-I $\beta$, IL-6, IL-21, IL-33 in OSA patients and nonOSA patients and reported significantly higher levels of IL6 and IL-33 in the mild/moderate and the severe OSA patients groups compared to the controls, $(\mathrm{p}<0.05) .3^{30} \mathrm{~A}$ statistically significant correlation was also identified between the IL-21 and both the CAL and the pocket depth $\mathrm{r}=-0.347(\mathrm{p}=0.017)$, and $\mathrm{r}=-0.287(\mathrm{p}=0.05)$, respectively, They concluded that the OSA patients may cause an increase in the salivary IL-6 and IL-33 levels independent of the OSA severity.

Numerous studies confound that various pathways include local and systemic inflammation leads to generation of pathogenesis of periodontal disease. OSA has been associated with an increased risk for development of metabolic disorders such as impaired glucose tolerance and insulin resistance. Gunaratnam et al. 7 did a pilot study they found prevalence of periodontitis among OSA patients and it was revealed that treatment of periodontitis has been shown to improve systemic inflammation, and metabolic control of glycemia which affects to periodontal health.

Nuha Ejaz et al. ${ }^{18}$ extended the findings of Gunaratnam et al.7 which diagnosed and classified periodontitis by same clinical parameter and suggested that the odds of moderate or severe periodontitis was elevated by a 4.1-fold margin among patients screening high risk relative to low risk for OSA after adjustment for potential confounders. Both studies suggested that the prevalence of periodontitis is greater in patients with OSA.

Day time somnolence, which a key indicator for OSA revealed a strong relationship with severity of periodontal disease as per Arora SA et al., ${ }^{19}$ who

assessed OSA by measuring daytime sleepiness using the Epworth sleepiness Scale. ${ }^{11}$ Studies revealed that a practicing dentist with fair knowledge of sleep related breathing disorders (SRBDs) are just as likely to identify a patient at risk of Sleep disorders as a physician, by careful dento-facial examination and using indices like ESS \& STOP Bang questionnaires. ${ }^{12}$

Rola Al Habashneh et al. ${ }^{20}$ (2016) justified association between periodontitis and high risk for OSA (HR -OSA) among patients who scored positive in two or more categories of the Berlin questionnaire ${ }^{12}$ as HR-OSA showed a higher pocket depth and clinical attachment level compared to patients with LR-OSA.

In contrast, Loke $\mathrm{W}$ et al. ${ }^{21}$ found no meaningful association between OSA and the prevalence of moderate/severe periodontitis.

\section{CONCLUSION}

Based on this review of literature, followed by systematic review of studies conducted in past years. Some studies extend the finding of Gunaratnam et al.7 (2009) that the prevalence of periodontitis may be higher in patients with OSA. Studies conducted by various screening questionnaire like ESS, STOP-Bang, Berlin Questionnaire, Mallampati index/score and Polysomnography. The clinical consequences of these findings suggest that physician should be encouraged to send their OSA patients to dentists for periodontal examination and urge compliance with dental appointments. Dentist also need to be educated and trained to identify sleep related breathing disorders, evaluate and screen them during chair side examination of OSA patients and treat them with oral appliances such as Mandibular Repositioning Devices, Tongue Repositioning Devices, pharmacotherapy and surgical management.

\section{REFERENCES}

1. Haffajee AD, Socransky SS. Microbial etiological agents of destructive periodontal diseases. Periodontology 1994 ;5(1):78-111.

2. Albandar JM, Brunelle JA, Kingman A. Destructive periodontal disease in adults 30 years of age and older in the United States, 1988-1994. Journal of periodontology 1999;70(1):1329.

3. Grossi SG, Genco RJ. Periodontal disease and diabetes mellitus: a two-way relationship. Annals of periodontology 1998;3(1):51-61.

4. Lőe H. Periodontal disease. The sixth complication of diabetes mellitus. Diabetes Care, 1993;16 :329-33410.

5. Fogel RB, Malhotra A, White DP. Sleep 2: pathophysiology of obstructive sleep apnea/hypopnoea syndrome. Thorax 2004;59:159-63.

6. Young T, Evans L, Finn L, Palta M. Estimation of the clinically diagnosed proportion of sleep apnea syndrome in middle-aged men and women. Sleep 1997;20(9):705-6.

7. Gunaratnam K, Taylor B, Curtis B, Cistulli P. Obstructive sleep apnoea and periodontitis: A novel association? Sleep Breath. 2009;13:233-9.

8. Kellar JJ, Wu CS, Chen YH, Lin HC. Association between Obstructive sleep and chronic Periodontitis: a population based study. J Periodontol. 2013;40: 111-7.

9. Arora SA, Chhina S, Goel A, Mishra S, Kazim J. Interconnect between Periodontal disease \& day time somnolence: A cross sectional study. NJIRM 2015;6(5):1-8.

10. Oksenberg A, Froom P, Melamed S. Dry mouth upon awakening in obstructive sleep apnea. J Sleep Res. 2006;15(3):317-20.

11. Ryan S, Taylor CT, McNicholas WT. Selective activation of inflammatory pathways by intermittent hypoxia in obstructive sleep apnea syndrome. Circulation 2005;112(17):2660-7.

12. Gharibeh T, Mehra R. Obstructive sleep apnea syndrome: natural history, diagnosis, and emerging treatment options. Nat Sci Sleep. 2010;2:233-55.

13. Johns MW. A new method for measuring daytime sleepiness: the Epworth sleepiness scale. Sleep 1991;14(6):540-5.

14. Netzer NC, Stoohs RA, Netzer CM, Clark K, Strohl KP. Using the Berlin Questionnaire to identify patients at risk 
for the sleep apnea syndrome. Ann Intern Med. 1999;131(7):485-91.

15. Ong TH, Raudha S, Fook-Chong S, Lew N, Hsu AAL. Simplifying STOP-Bang: use of a simple questionnaire to screen for OSA in an Asian population. Sleep Breath 2010;14:3716.

16. Iber C, Ancoli-Israel S, Chesson A. "Quan SF, for the American Academy of Sleep Medicine: The AASM manual for the scoring of sleep and associated events: rules, terminology and technical specifications." (2007).

17. Al Habashneh R, Khassawneh B, Khader YS, Abu-Jamous Y, Kowolik MJ. Association Between Obstructive Sleep Apnea and Periodontitis Among Male Adults Attending a Primary Healthcare Facility in Jordan. Oral health \& preventive dentistry 2015;14(2):157-64.

18. Suzuki S, Kojima Y, Takayanagi A, Yoshino K, Ishizuka $\mathrm{Y}$, Satou R, et al. Relationship between

Obstructive Sleep Apnea and Self-assessed Oral Health Status: An Internet Survey. The Bulletin of Tokyo Dental College. 2016;57(3):175-81.

19. Gamsiz-Isik H, Kiyan E, Bingol Z, Baser U, Ademoglu E, Yalcin F. Does Obstructive Sleep Apnea Increase the Risk for Periodontal Disease?: A Case-control Study. J Periodontol. 2016; 18:1-8.

20. Loke W, Girvan T, Ingmundson P, Verret R, Schoolfield $\mathrm{J}$, Brian LM. Investing the Association between Obstructive Sleep Apnea and Periodontitis. J Periodontol 2015; 86: 232-243.

21. Seo WH, Cho ER, Thomas RJ, An SY, Ryu JJ, Kim H, Shin C. The association between periodontitis and obstructive sleep apnea: a preliminary study. Journal of periodontal research 2013;48(4):500-6.
22. Al-Jewair TS, Al-Jasser R, Almas K. Periodontitis and obstructive sleep apnea's bidirectional relationship: a systematic review and meta-analysis. Sleep and Breathing. 2015;19(4):1111-20.

23.Grossi SG, Genco RJ. Periodontal disease and diabetes mellitus: a two-way relationship. Annals of periodontology 1998;3(1):51-61.

24. Punjabi NM, Ahmed MM, Polotsky VY, Gottlieb DJ, Givelber R, Resnick HE, et al. Sleep disordered breathing, glucose intolerance, and insulin resistance. Respir Physiol Neurobiol. 2003;136(2-3):167-78.

25. Nizam N, Basoglu OK, Tasbakan MS, Nalbantsoy A, Buduneli N. Salivary cytokines and the association between obstructive sleep apnea syndrome and periodontal disease. J Periodontol 2014;85:251-8.

26. Howells GL. Cytokine networks in destructive periodontal disease. Oral Dis 1995;1:266-270.

27. Loos BG. Systemic markers of inflammation in periodontitis. J Periodontol 2005;76:2106-15.

28. Shamsuzzaman AS, Winnicki M, Lanfranchi P, Wolk R, Kara T, Accurso V, et al. Elevated C-reactive protein in patients with obstructive sleep apnea. Circulation 2002;105(21):2462-4.

29. Ryan S, Taylor CT, McNicholas WT. Selective activation of inflammatory pathways by intermittent hypoxia in obstructive sleep apnea syndrome. Circulation, 2005;112(17):2660-7.

30. Nizam N, Basoglu OK, Tasbakan MS, Holthöfer A, Tervahartiala $\mathrm{T}$, Sorsa $\mathrm{T}$, et al. Do salivary and serum collagenases have a role in an association between obstructive sleep apnea syndrome and periodontal disease? A preliminary case-control study. Arch Oral Biol 2014;60:134-43. 